\title{
Predicting Resistance by Mutagenesis: Lessons from 45 Years of MBC Resistance
}

\author{
Nichola J. Hawkins* and Bart A. Fraaije \\ Biological Chemistry and Crop Protection, Rothamsted Research, Harpenden, UK
}

When a new fungicide class is introduced, it is useful to anticipate the resistance risk in advance, attempting to predict both risk level and potential mechanisms. One tool for the prediction of resistance risk is laboratory selection for resistance, with the mutational supply increased through UV or chemical mutagenesis. This enables resistance to emerge more rapidly than in the field, but may produce mutations that would not emerge under field conditions. The methyl benzimidazole carbamates (MBCs) were the first systemic single-site agricultural fungicides, and the first fungicides affected by rapid evolution of target-site resistance. MBC resistance has now been reported in over

OPEN ACCESS

Edited by:

Sabine Fillinger,

Institut National de la Recherche

Agronomique, France

Reviewed by:

Melvin Bolton,

U.S. Department of Agriculture, USA

Guido Schnabel,

Clemson University, USA

${ }^{*}$ Correspondence:

Nichola J. Hawkins

nichola.hawkins@rothamsted.ac.uk

Specialty section:

This article was submitted to

Antimicrobials, Resistance

and Chemotherapy,

a section of the journal

Frontiers in Microbiology

Received: 07 September 2016

Accepted: 28 October 2016

Published: 15 November 2016

Citation:

Hawkins NJ and Fraaije BA (2016)

Predicting Resistance by

Mutagenesis: Lessons from 45 Years

of MBC Resistance.

Front. Microbiol. 7:1814

doi: 10.3389/fmicb.2016.01814
90 plant pathogens in the field, and laboratory mutants have been studied in nearly 30 species. The most common field mutations, including $\beta$-tubulin E198A/K/G, F200Y and L240F, have all been identified in laboratory mutants. However, of 28 mutations identified in laboratory mutants, only nine have been reported in the field. Therefore, the predictive value of mutagenesis studies would be increased by understanding which mutations are likely to emerge in the field. Our review of the literature indicates that mutations with high resistance factors, and those found in multiple species, are more likely to be reported in the field. However, there are many exceptions, possibly due to fitness penalties. Whether a mutation occurred in the same species appears less relevant, perhaps because $\beta$-tubulin is highly conserved so functional constraints are similar across all species. Predictability of mutations in other target sites will depend on the level and conservation of constraints.

Keywords: fungicide resistance, plant pathogens, benzimidazoles, mutagenesis, in vitro selection, predictability, fitness penalties, functional constraints

\section{INTRODUCTION}

The loss of effective fungicide classes due to the evolution of resistance in key target pathogens is a major threat to crop protection. The methyl benzimidazole carbamates (MBCs), or benzimidazoles, were the first single-site fungicides, and the first cases of $\mathrm{MBC}$ resistance were reported soon after their introduction. This was followed by the introduction of, and subsequent emergence of resistance to, the 2-aminopyrimidine mildewicides; the phenylamide oomyceticides; the demethylation inhibitor (DMI) fungicides, including azoles; and the Quinone outside Inhibitor (QoI) fungicides, or strobilurins (Lucas et al., 2015). In contrast, cases of resistance against multi-site inhibitors remain rare (Grimmer et al., 2014). 
With the recent introduction of new succinate dehydrogenase inhibitors (SDHIs), it was realized that resistance would be a risk. Consequently, mutagenesis and laboratory selection experiments were carried out to assess the resistance risk and possible mechanisms in advance of resistance emerging in the field (Fraaije et al., 2012; Scalliet et al., 2012). These experiments use UV irradiation as a mutagen, increasing the mutational supply, coupled with strong selection from a discriminatory dose of fungicide within the growth medium.

These laboratory selection experiments rapidly produced resistant mutants carrying a range of target-site mutations, correlated with a range of resistance factors. However, questions remained as to which of these mutations would actually emerge in the field: whether a single highly resistant genotype would dominate as seen with the QoIs; or whether the range of mutations and resistance factors gave cause for optimism that resistance may emerge in the slower, step-wise fashion seen with the azoles.

We consider mutagenesis studies carried out with MBC selection in the light of over 45 years of field resistance reports, comparing the mutations produced in the laboratory with those that have actually been reported in the field.

\section{MBC RESISTANCE}

The first published case of $\mathrm{MBC}$ resistance was in cucurbit powdery mildew in 1969 (Schroeder and Provvidenti, 1969), followed by Botrytis in grapevine in 1971 (Ehrenhardt et al., 1973), and cereal powdery mildew in 1973 (Vargas, 1973). Resistance has now been reported in over 90 different plant pathogens in the field (Fungicide Resistance Action Committee, 2013).

Since the introduction of MBCs and the first reports of field resistance, mutagenesis studies have also been carried out. Initially these studies were carried out in the model fungi Saccharomyces cerevisiae (Thomas et al., 1985), Neurospora crassa (Borck and Braymer, 1974; Orbach et al., 1986; Fujimura et al., 1992), and Aspergillus nidulans (Jung and Oakley, 1990; Jung et al., 1992), in order to confirm the mode of action and resistance mechanism. Subsequent studies have sought to determine the potential for $\mathrm{MBC}$ resistance in other plant pathogen species (Wheeler et al., 1995; Albertini et al., 1999; Ziogas et al., 2009), clinical pathogens (Cruz and Edlind, 1997), and phytopathogen biocontrol agents (Olejnikova et al., 2010).

When field resistance was first reported (Schroeder and Provvidenti, 1969), the resistance mechanism was unknown. Laboratory mutants in model species were then used in protein binding studies (Davidse and Flach, 1977) and protein electrophoresis (Sheir-Neiss et al., 1978), demonstrating reduced fungicide binding and altered electrophoretic properties of the target protein from resistant mutants, identified as tubulin and specifically $\beta$-tubulin. This was followed by gene cloning (Orbach et al., 1986) and sequencing (Thomas et al., 1985; Fujimura et al., 1990) of $\beta$-tubulin from resistant mutants, identifying the individual mutations responsible. Some two decades after the first reports of field resistance, Koenraadt et al. (1992) reported target-site mutations in $\mathrm{MBC}$-resistant field isolates of plant pathogens. The $\beta$-tubulin mutations responsible for $\mathrm{MBC}$ resistance in field isolates have now been published for 29 fungal species.

\section{LAB AND FIELD}

Mutagenesis studies have undoubtedly proven useful in mode of action studies, identifying the target sites of fungicides and the gene that would be involved in target-site resistance. However, mutagenesis studies are sometimes also used to predict which mutations within that gene may confer resistance in the field. We analyse the accuracy of such predictions in the case of MBC resistance.

The first $\beta$-tubulin mutations reported in field isolates resulted in E198A, E198K, E198V, or F200Y amino acid substitutions (Koenraadt et al., 1992). These mutations have since been reported in a range of other pathogens, along with a further eight non-synonymous mutations. The most-reported substitutions across species are E198A in 20 species, and F200Y in 14 species. E198K has been reported in 12 species; E198G in six; L240F in four; F167Y and E198L in three species each; E198Q and E198V in two species; and H6Y, Y50C and Q73R, each in a single species (Figure 1; Supplementary Table 1). Y167 has also been reported in the intrinsically resistant Cochliobolus heterostrophus and Stemphylium species (Gafur et al., 1998; Huang et al., 2013).

Methyl benzimidazole carbamate-resistant laboratory mutants have been reported in nearly 30 fungal species (Fungicide Resistance Action Committee, 2013). The $\beta$-tubulin mutations in those mutants have been published for 15 of those species (Supplementary Table 1). The most common mutations in laboratory mutants are at codon 198, as they are for field isolates. However, in laboratory mutants, the substitutions E198K and E198G are found in more species than E198A. F167Y and H6Y are also reported in laboratory mutants in multiple species, and have been found in the field as well. However, many other laboratory mutations have not yet been reported in the field: of 28 reported amino acid changes in laboratory mutants, only nine have been reported in the field, leaving 19 substitutions predicted by mutagenesis studies that have yet to be found in field isolates. In contrast, only a further three non-synonymous changes have been reported in field isolates without having been identified in laboratory mutants.

Therefore, laboratory mutagenesis studies can identify a range of potential mutations, of which a subset may occur in the field. This raises the question of why some mutations occur in the field and others do not, and whether the predictive power of mutagenesis studies can be improved by assessing which mutations are most likely to be reported in field isolates.

\section{RESISTANCE FACTORS}

One possibility is that the most resistant mutants will be reported in the field. This may be due to a higher emergence rate of such 


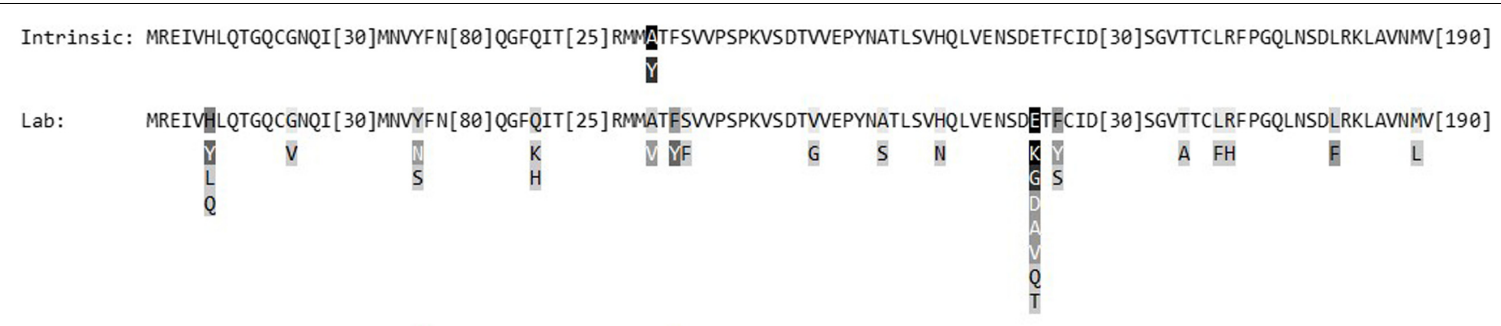

Field: MREIVHLQTGQCGNQI [30]MNVYFN[75]QGFQIT[25] RMMATFSWPSPKVSDTVVEYNATLSVHQLVENSDETFECID [30]SGVTTCLRFPGQLNSDLRKLAVNMV[190] $\mathrm{Y}$ C $\square$

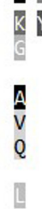

FIGURE 1 | Summary of key $\beta$-tubulin amino acid substitutions in intrinsically resistant fungal species, and resistant laboratory mutants and field isolates of other fungal species. Top lines: wild-type consensus sequence; darker shading indicates residues at which substitutions occur in more species. Square brackets: omitted residues (no substitutions). Letters under sequences: substituting amino acids in resistant mutants/isolates; darker shading indicates substitutions occurring in more species.

mutations due to stronger positive selection by fungicides, or due to reporting bias since highly resistant isolates are more likely to result in control failures prompting further investigation.

Sensitivity data were included in 12 published mutagenesis studies. Sensitivity data reported as $\mathrm{MIC}$ or $\mathrm{EC}_{50}$ values were converted to resistance factors. Geometric means of resistance factors were calculated where multiple data were available for a single mutation. We assumed general positive crossresistance between $\mathrm{MBC}$ fungicides where different fungicides were tested in different species but excluded data for N-phenylcarbamates such as diethofencarb. The number of species in which each mutation has been reported in the field was plotted against the average resistance factor for that mutation (Figure 2).

Out of those mutations for which laboratory mutant sensitivity data were available, four of the top six mutations by resistance factors were the top four mutations reported in the most species in the field (E198E, E198G, E198K, and F200Y). Mutations with lower resistance factors have been reported in fewer or no species in the field, which may be due to insufficient selective pressure in the field, or insufficient resistance to prompt investigation. However, there is scatter within the higher and lower groups and there is no significant correlation overall.

Two substitutions with high resistance factors but not reported in the field are G13V and S168F, both found in Trichoderma harzianum (Li et al., 2013). The S168F mutant had the highest resistance factor with a 1572-fold increase in $\mathrm{EC}_{50}$ compared to the wild-type, and the G13V mutant had a 96fold increase. When mutants are found in the laboratory and not in the field, fitness penalties are often invoked as a possible explanation. Both of those mutants appeared to exhibit normal growth in culture, although fitness was not tested under field conditions. However, since both mutations were reported in the same species and within the same study, it is possible that these data points reflect problems with comparing data from different experimental systems and assay methods.
In other studies, mutants have been found to carry fitness penalties, often in the form of increased temperature sensitivity. Microtubule dynamics within a cell require both the polymerisation and depolymerisation of tubulin. Therefore, there will be fitness penalties both for $\beta$-tubulin alterations causing reduced binding affinity, especially at higher temperatures; and for alterations causing stronger binding, especially in lower temperatures. In S. cerevisiae, Thomas et al. (1985) reported six cold-sensitive mutants including $\mathrm{R} 241 \mathrm{H}$, and three coldsensitive mutants; Li et al. (1996) report that F167Y also confers cold-sensitivity. In Fusarium moniliforme, Y50N mutants were fungicide-sensitive at low temperatures but could grow in the absence of fungicides (Yan and Dickman, 1996). In B. bassiana, Zou et al. (2006) reported mutant haplotypes with up to six $\beta$-tubulin mutations with a range of sensitivity levels, with reduced thermal tolerance in the more resistant mutants. In $A$. nidulans, benA33 mutants were cold-sensitive due to microtubule hyperstability (Oakley and Morris, 1981; Davidse, 1986), whereas mutations Y50N, Y50S, Q134K, and M257L were associated with heat-sensitivity (Koenraadt et al., 1992). However, Weatherbee and Morris (1984) describe "revertants" growing at high temperatures, some of which retained MBCresistance, indicating that compensatory mutations are possible. Furthermore, Ma et al. (2003) report temperature sensitivity in field isolates of Monilinia fructicola with H6Y isolates coldsensitive and E198A isolates heat-sensitive, and Trkulja et al. (2013) report that MBC-resistance is cold-sensitive in F167Y isolates of Cercospora beticola, demonstrating that fitness costs involving temperature-sensitivity may not prevent the emergence of a mutation in the field.

\section{OCCURRENCE IN DIFFERENT SPECIES}

Another hypothesis was that a mutation having been selected repeatedly in mutagenesis studies across different species would 
A

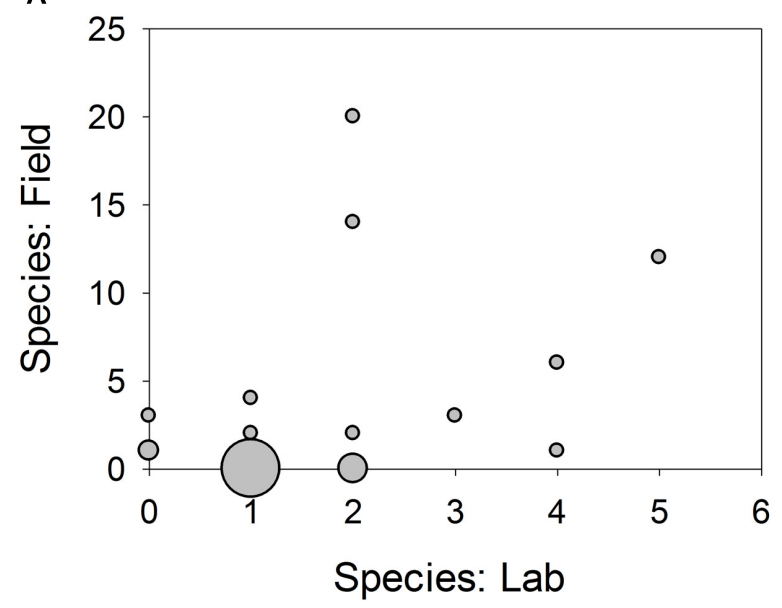

B

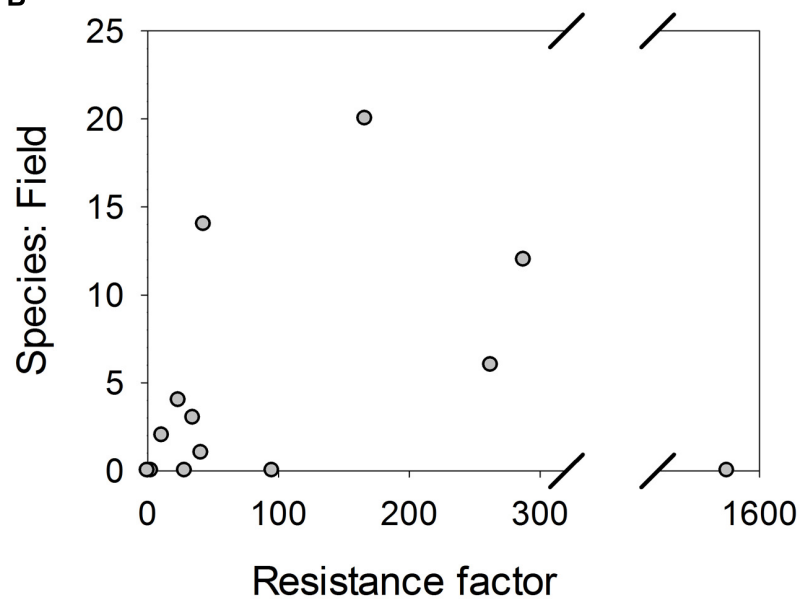

FIGURE 2 | Scatter plots showing the number of species in which a $\beta$-tubulin substitution has been reported in MBC-resistant field isolates, against (A) the number of species in which that mutation has been reported in laboratory isolates; (B) the mean resistance factor of mutants with that substitution based on published sensitivity data. Symbol area is proportional to number of substitutions.

indicate that it is more likely to be found in the field. The number of species in which each mutation has been reported in the field was plotted against the number of species in which that mutation had been generated in laboratory mutants.

There was no overall correlation between the number of species in which a mutation was reported in the field and in laboratory mutants. However, mutations found in multiple species in the laboratory were more likely to be found in the field at all. All four mutations reported in laboratory mutants of three or more species (E198K, E198G, F167Y, and H6Y) have been reported in at least one species in the field, compared to three out of seven mutations each reported in laboratory mutants of two species; just two out of 17 mutations reported in laboratory mutants of a single species; and three out of the 8503 potential amino acid substitutions not reported in laboratory mutants.

A further question is whether mutations are more likely to emerge in the field in a given species if they have occurred in laboratory mutants of that species, compared to having occurred in mutants of any species. There are only six species for which $\beta$-tubulin mutations have been published both from laboratory mutagenesis studies and from MBC-resistant field isolates. Within those six species, an average of 2.67 mutations per species have been reported in laboratory mutants and 2.67 mutations per species in field isolates, of which 0.67 mutations are found in both laboratory and field strains of that same species. Over the six species as a whole, a total of 14 mutations were reported in laboratory mutants; of the 2.67 mutations per species and seven mutations in total in field isolates, all had been found in laboratory mutants.

Therefore, if data are limited to the same species, $25 \%$ of laboratory mutations were found in the field, $25 \%$ of field mutations were found in laboratory and $14 \%$ of the total mutations were found both in laboratory mutants and in field isolates. If field mutations within each species are compared to laboratory mutations across the six species, only $19 \%$ of laboratory mutations are found in field but $100 \%$ of field mutations were found in the laboratory, with $19 \%$ of total mutations found in both laboratory and field strains. If laboratory and field mutations are considered across the six species, 50\% of laboratory mutations are found in field isolates, $100 \%$ of field mutations had been reported in laboratory mutants, with 50\% total overlap.

These figures appear mainly to reflect sampling effects. If more species are considered, there is more coverage of all potential mutation space, leading to more overlap between laboratory and field mutations. The species in which the mutations occurred appears to be less relevant: this is likely to be due to the conserved nature of the target site. Fungal $\beta$-tubulin is a highly conserved protein, and therefore its evolution in response to fungicide selection is likely to be determined by similar functional constraints across species. It remains to be seen whether this apparent species-independence is generally true for mutagenesis studies, or whether other molecular targets have more lineagespecific constraints.

This has implications as to whether it is useful to carry out mutagenesis in a new target species if similar studies have already been carried out in other fungi. These results suggest that mutagenesis in additional species would be useful since it increases the total sampling of mutations, but for conserved targets like $\beta$-tubulin it could be more useful to generate plenty of mutants in an easy-to-grow, readily mutated laboratory model than to struggle with a less tractable target pathogen.

\section{MUTATED CODON POSITIONS}

Finally, we consider whether the predictive power of mutagenesis studies is higher in terms of the codons at which substitutions will occur than for the specific substitutions. For specific substitutions, $24 \%$ of laboratory mutations have been reported 
in the field and $42 \%$ of field mutations had been reported in the laboratory, with $29 \%$ total in overlap. For codon position only, $26 \%$ of residues altered in laboratory mutants were also altered in field isolates and $46 \%$ of residues altered in field isolates had also been altered in laboratory mutants, with 33\% total overlap. Therefore, by considering only the codon and not the specific substitution, the overlap rate is marginally higher. However, substantially less of the total possible mutational space is excluded. Of 449 codons in the fungal $\beta$-tubulin consensus sequence, 18 have reported mutations, which is approximately 1 in 40 . Out of 8531 possible substitutions, 31 have been reported, which is approximately 1 in 500. Therefore, considering codons only leads to a marginally lower error rate but a substantially lower information content.

The main exception to this is where mutagenesis was carried out using chemical mutagens that have a substitution bias and so are more likely to introduce a different substitution at the same codon. In Colletotrichum gloeosporioides, E198K was reported in laboratory mutants whereas E198A is more common in the field, since the mutagen used, EMS, introduces A:T nucleotide transitions whereas E198A requires an A:C transversion (Buhr and Dickman, 1994; Lucas et al., 2015). In contrast, UV mutagenesis produces a range of mutations, with all 12 possible nucleotide substitutions found within MBC-selected laboratory mutants.

\section{FUTURE PROSPECTS}

Following the MBCs, further single-site fungicide classes have been introduced and resistance has subsequently emerged. In the case of the QoIs, the picture is somewhat simpler. A single mutation, G143A, is responsible for the majority of field resistance; an alternative mutation, F129L, occurs mostly in species where the mutation encoding G143A would prevent the correct splicing of an intron after codon 143; and a third alternative, G137R, at very low frequency in a single species (Sierotzki et al., 2007). In contrast, the picture for azoles is far more complex, with over 30 reported mutations in Zymoseptoria tritici alone, combining in multi-mutation haplotypes (Cools and Fraaije, 2013). This is further complicated by the incomplete cross-resistance between different compounds within the DMI group (Cools et al., 2013), so a mutagenesis study selecting with one azole may produce different mutations from selection with another.

Therefore, the use of mutagenesis has been limited for both fungicide classes, perhaps for opposite reasons: in QoIs, because the rapid emergence of a single, overwhelmingly prevalent mutation has made such studies unnecessary; and in azoles, far more extensive studies would be required to produce meaningful results. For the QoIs, Geier et al. (1992) report two cytochrome $b$ mutations including G137R in yeast mutants and Malandrakis

\section{REFERENCES}

Albertini, C., Gredt, M., and Leroux, P. (1999). Mutations of the $\beta$-tubulin gene associated with different phenotypes of benzimidazole resistance in the cereal et al. (2006) report six different mutations including G143A and F129V in laboratory mutants of C. beticola. For the azoles, Chen et al. (2012) identified the CYP51 substitution Y136F, which has been reported in several species in the field, in laboratory mutants of $M$. fructicola. The CYP51A substitution G54W has been reported in laboratory mutants of $A$. parasiticus (Doukas et al., 2012) and clinical isolates of A. fumigatus (Diaz-Guerra et al., 2003). Krishnan-Natesan et al. (2008) generated A. flavus mutants, reporting five mutations in CYP51A and four different mutations in CYP51B, none known from clinical Aspergillus isolates. Doukas et al. (2012) also obtained mutants with an MDR phenotype, as seen in resistant field isolates of plant pathogens with enhanced efflux (Hayashi et al., 2001; Leroux and Walker, 2011). Fan et al. (2014) report a proposed lossof-function mutation in CYP51B resulting in over-expression of CYP51A in F. verticillioides, and Jackson et al. (2003) report sterol desaturase loss-of-function mutants in S. cerevisiae.

For the most recently introduced class of ascomycete-active SDHIs, mutagenesis studies were carried out prior to their introduction in the field (Fraaije et al., 2012; Scalliet et al., 2012). Early reports of field resistance (FRAC SDHI Working Group, 2015) are consistent with the pattern noted for MBCs: laboratory mutagenesis generates a wide variety of mutations, of which a subset will be reported in the field. The use of functional genetic approaches such as homologous gene replacement will allow more precise measurements of the impact of each mutation on fungicide sensitivity and of any associated fitness penalties, and it is hoped that a better understanding of the underlying fitness landscape will improve the predictive power of laboratory studies of resistance in future.

\section{AUTHOR CONTRIBUTIONS}

$\mathrm{NH}$ contributed to the conception and design of the work, carried out the literature search and meta-analyses, and drafted the manuscript. BF contributed to the conception and design of the work and critically revised the manuscript.

\section{FUNDING}

Rothamsted Research receives grant-aided support from the Biotechnology and Biological Sciences Research Council (BBSRC) of the United Kingdom.

\section{SUPPLEMENTARY MATERIAL}

The Supplementary Material for this article can be found online at: http://journal.frontiersin.org/article/10.3389/fmicb. 2016.01814/full\#supplementary-material

eyespot fungi Tapesia yallundae and Tapesia acuformis. Pestic. Biochem. Physiol. 64, 17-31. doi: 10.1006/pest.1999.2406

Baraldi, E., Mari, M., Chierici, E., Pondrelli, M., Bertolini, P., and Pratella, G. C. (2003). Studies on thiabendazole resistance of Penicillium expansum of pears: 
pathogenic fitness and genetic characterization. Plant Pathol. 52, 362-370. doi: 10.1046/j.1365-3059.2003.00861.x

Borck, K., and Braymer, H. D. (1974). The genetic analysis of resistance to benomyl in Neurospora crassa. J. Gen. Microbiol. 85, 51-56. doi: 10.1099/0022128785-1-51

Buhr, T. L., and Dickman, M. B. (1994). Isolation, characterization, and expression of a 2nd $\beta$-tubulin-encoding gene from Colletotrichum gloeosporioides f.sp. aeschynomene. Appl. Environ. Microbiol. 60, 4155-4159.

Burns, P. A., Allen, F. L., and Glickman, B. W. (1986). DNA sequence analysis of mutagenicity and site specificity of ethyl methylsulfonate in UVR+ and UVRBstrains of Escherichia coli. Genetics 113, 811-819.

Canas-Gutierrez, G. P., Patino, L. F., Rodriguez-Arango, E., and Arango, R. (2006). Molecular characterization of benomyl-resistant isolates of Mycosphaerella fijiensis, collected in Colombia. J. Phytopathol. 154, 403-409. doi: 10.1111/j.1439-0434.2006.01113.x

Carter, H. E., Cools, H. J., West, J. S., Shaw, M. W., and Fraaije, B. A. (2013). Detection and molecular characterisation of Pyrenopeziza brassicae isolates resistant to methyl benzimidazole carbamates. Pest. Manag. Sci. 69, 1040-1048. doi: $10.1002 /$ ps.3585

Chen, C. J., Yu, J. J., Bi, C. W., Zhang, Y. N., Xu, J. Q., Wang, J. X., et al. (2009). Mutations in a $\beta$-tubulin confer resistance of Gibberella zeae to benzimidazole fungicides. Phytopathology 99, 1403-1411. doi: 10.1094/phyto-9912-1403

Chen, F. P., Fan, J. R., Zhou, T., Liu, X. L., Liu, J. L., and Schnabel, G. (2012). Baseline sensitivity of Monilinia fructicola from China to the DMI fungicide SYP-Z048 and analysis of DMI-resistant mutants. Plant Dis. 96, 416-422. doi: 10.1094/pdis-06-11-0495

Cooley, R. N., and Caten, C. (1993). Molecular analysis of the Septoria nodorum $\beta$-tubulin gene and characterization of a benomyl-resistance mutation. Mol. Gen. Genet. 237, 58-64. doi: 10.1007/BF00282784

Cools, H. J., and Fraaije, B. A. (2013). Update on mechanisms of azole resistance in Mycosphaerella graminicola and implications for future control. Pest. Manag. Sci. 69, 150-155. doi: 10.1002/ps.3348

Cools, H. J., Hawkins, N. J., and Fraaije, B. A. (2013). Constraints on the evolution of azole resistance in plant pathogenic fungi. Plant Pathol. 62, 36-42. doi: $10.1111 /$ ppa. 12128

Cruz, M. C., and Edlind, T. (1997). $\beta$-Tubulin genes and the basis for benzimidazole sensitivity of the opportunistic fungus Cryptococcus neoformans. Microbiology 143, 2003-2008. doi: 10.1099/00221287-143-6-2003

Cunha, M. G., and Rizzo, D. M. (2003). Development of fungicide cross resistance in Helminthosporium solani populations from California. Plant Dis. 87, 798-803. doi: 10.1094/pdis.2003.87.7.798

Davidse, L. C. (1986). Benzimidazole fungicides: mechanism of action and biological impact. Annu. Rev. Phytopathol. 24, 43-65. doi: 10.1146/annurev.py.24.090186.000355

Davidse, L. C., and Flach, W. (1977). Differential binding of methyl benzimidazol2-yl carbamate to fungal tubulin as a mecchanism of resistance to this antimitotic agent in mutant strains of Aspergillus nidulans. J. Cell Biol. 72, 174-193. doi: 10.1083/jcb.72.1.174

Davidson, R. M., Hanson, L. E., Franc, G. D., and Panella, L. (2006). Analysis of $\beta$-tubulin gene fragments from benzimidazole-sensitive and tolerant Cercospora beticola. J. Phytopathol. 154, 321-328. doi: 10.1111/j.14390434.2006.01080.x

Diaz-Guerra, T. M., Mellado, E., Cuenca-Estrella, M., and Rodriguez-Tudela, J. L. (2003). A point mutation in the 14 alpha-sterol demethylase gene cyp51A contributes to itraconazole resistance in Aspergillus fumigatus. Antimicrob. Agents Chemother. 47, 1120-1124. doi: 10.1128/AAC.47.3.1120-1124.2003

Doukas, E. G., Markoglou, A. N., Vontas, J. G., and Ziogas, B. N. (2012). Effect of DMI-resistance mechanisms on cross-resistance patterns, fitness parameters and aflatoxin production in Aspergillus parasiticus speare. Fungal Genet. Biol. 49, 792-801. doi: 10.1016/j.fgb.2012.07.008

Ehrenhardt, H., Eichhorn, K. W., and Thate, R. (1973). Zur Frage der Resistenzbildung von Botrytis cinerea gegenuber systemischen Fungiziden. Nachr. Deutsch. Pflanzenschutzd. 25, 49-50.

Fan, J., Chen, F., Diao, Y., Cools, H. J., Kelly, S. L., and Liu, X. (2014). The Y123H substitution perturbs FvCYP51B function and confers prochloraz resistance in laboratory mutants of Fusarium verticillioides. Plant Pathol. 63, 952-960. doi: $10.1111 /$ ppa. 12168
Fraaije, B. A., Bayon, C., Atkins, S., Cools, H. J., Lucas, J. A., and Fraaije, M. W. (2012). Risk assessment studies on succinate dehydrogenase inhibitors, the new weapons in the battle to control Septoria leaf blotch in wheat. Mol. Plant Pathol. 13, 263-275. doi: 10.1111/j.1364-3703.2011. 00746.x

Fraaije, B. A., Cools, H. J., Fountaine, J., Lovell, D. J., Motteram, J., West, J. S., et al. (2005). Role of Ascospores in further spread of QoI-resistant cytochrome $b$ alleles (G143A) in field populations of Mycosphaerella graminicola. Phytopathology 95, 933-941. doi: 10.1094/PHYTO-95-0933

FRAC SDHI Working Group (2015). List of Species Resistant to SDHIs April 2015 [Online]. www.frac.info: Fungicide Resistance Action Committee. Available at: http://www.frac.info/docs/default-source/sdhi-wg/sdhi-references/listof-species-resistant-to-sdhis-april-2015.pdf?sfvrsn=2 [accessed August 25, 2016]

Fujimura, M., Kamakura, T., Inoue, H., Inoue, S., and Yamaguchi, I. (1992). Sensitivity of Neurospora crassa to benzimidazoles and N-phenylcarbamates effect of amino-acid substitutions at position 198 in $\beta$-tubulin. Pestic. Biochem. Physiol. 44, 165-173. doi: 10.1016/0048-3575(92)90087-g

Fujimura, M., Kamakura, T., Inoue, H., and Yamaguchi, I. (1994). Aminoacid alterations in the $\beta$-tubulin gene of Neurospora crassa that confer resistance to carbendazim and diethofencarb. Curr. Genet. 25, 418-422. doi: $10.1007 / \mathrm{bf} 00351780$

Fujimura, M., Oeda, K., Inoue, H., and Kato, T. (1990). "Mechanism of action of Nphenylcarbamates in benzimidazole-resistant neurospora strains," in Managing Resistance to Agrochemicals: From Fundamental Research to Practical Strategies, eds M. B. Green, H. M. LeBaron, and W. K. Moberg (Washington, DC: American Chemical Society).

Fungicide Resistance Action Committee (2013). List of Plant Pathogenic Organisms Resistant to Disease Control Agents. Fungicide Resistance Action Committee. Available at: http://www.frac.info/docs/default-source/ publications/list-of-resistant-plant-pathogens/list-of-resistant-plant-pathog enic-organisms-february-2013.pdf?sfvrsn=4 [accessed May 13, 2013].

Gafur, A., Tanaka, C., Shimizu, K., Ouchi, S., and Tsuda, M. (1998). Molecular analysis and characterization of the Cochliobolus heterostrophus $\beta$-tubulin gene and its possible role in conferring resistance to benomyl. J. Gen. Appl. Microbiol. 44, 217-223. doi: 10.2323/jgam.44.217

Geier, B. M., Schagger, H., Brandt, U., Colson, A. M., and Vonjagow, G. (1992). Point mutation in cytochrome- $b$ of yeast ubihydroquinone - cytochrome- $c$ oxidoreductase causing myxothiazol resistance and facilitated dissociation of the iron-sulfur subunit. Eur. J. Biochem. 208, 375-380. doi: 10.1111/j.14321033.1992.tb17197.x

Goldman, G. H., Temmerman, W., Jacobs, D., Contreras, R., Vanmontagu, M., and Herreraestrella, A. (1993). A nucleotide substitution in one of the $\beta$-tubulin genes of Trichoderma viride confers resistance to the antimitotic drug methyl benzimidazole-2-yl-carbamate. Mol. Gen. Genet. 240, 73-80. doi: 10.1007/BF00276886

Grimmer, M. K., van den Bosch, F., Powers, S. J., and Paveley, N. D. (2014). Evaluation of a matrix to calculate fungicide resistance risk. Pest Manag. Sci. 70, 1008-1016. doi: 10.1002/ps.3646

Hayashi, K., Schoonbeek, H. J., Sugiura, H., and De Waard, M. A. (2001). Multidrug resistance in Botrytis cinerea associated with decreased accumulation of the azole fungicide oxpoconazole and increased transcription of the ABC transporter gene BcatrD. Pestic. Biochem. Physiol. 70, 168-179. doi: 10.1006/pest.2001.2548

Huang, D. Y., Shi, Y. X., Xie, X. W., Wang, W. P., and Li, B. J. (2013). Characterization of the $\beta$-tubulin genes from Stemphylium species. J. Pure Appl. Microbiol. 7, 3131-3135.

Jackson, C. J., Lamb, D. C., Manning, N. J., Kelly, D. E., and Kelly, S. L. (2003). Mutations in Saccharomyces cerevisiae sterol C5-desaturase conferring resistance to the CYP51 inhibitor fluconazole. Biochem. Biophys. Res. Commun. 309, 999-1004. doi: 10.1016/j.bbrc.2003.08.098

Jung, M. K., and Oakley, B. R. (1990). Identification of an amino acid substitution in the benA, $\beta$-tubulin gene of Aspergillus nidulans that confers thiabendazole resistance and benomyl supersensitivity. Cell Motil. Cytoskeleton 17, 87-94. doi: $10.1002 / \mathrm{cm} .970170204$

Jung, M. K., Wilder, I. B., and Oakley, B. R. (1992). Amino acid alterations in the benA ( $\beta$-tubulin) gene of Aspergillus nidulans that confer benomyl resistance. Cell Motil. Cytoskeleton 22, 170-174. doi: 10.1002/cm.970220304 
Koenraadt, H., and Jones, A. L. (1993). Resistance to benomyl conferred by mutations in codon-198 or codon-200 of the $\beta$-tubulin gene of Neurospora crass $a$ and sensitivity to diethofencarb conferred by codon-198. Phytopathology 83, 850-854. doi: 10.1094/Phyto-83-850

Koenraadt, H., Somerville, S. C., and Jones, A. L. (1992). Characterisation of mutations in the $\beta$-tubulin gene of benomyl-resistant field strains of Venturia inaequalis and other plant pathogenic fungi. Phytopathology 82, 1348-1354. doi: 10.1094/Phyto-82-1348

Krishnan-Natesan, S., Chandrasekar, P. H., Alangaden, G. J., and Manavathu, E. K. (2008). Molecular characterisation of cyp51A and cyp51B genes coding for P450 14 alpha-lanosterol demethylases A (CYP51Ap) and B (CYP51Bp) from voriconazole-resistant laboratory isolates of Aspergillus flavus. Int. J. Antimicrob. Agents 32, 519-524. doi: 10.1016/j.ijantimicag.2008. 06.018

Leroux, P., and Walker, A. S. (2011). Multiple mechanisms account for resistance to sterol $14 \alpha$-demethylation inhibitors in field isolates of Mycosphaerella graminicola. Pest. Manag. Sci. 67, 44-59. doi: 10.1002/ps.2028

Li, J., Katiyar, S. K., and Edlind, T. D. (1996). Site-directed mutagenesis of Saccharomyces cerevisiae $\beta$-tubulin: interaction between residue 167 and benzimidazole compounds. FEBS Lett. 385, 7-10. doi: 10.1016/00145793(96)00334-1

Li, M., Zhang, H. Y., and Liang, B. (2013). Novel Mutations in $\beta$-Tubulin Gene in Trichoderma harzianum mutants resistant to methyl benzimidazol-2-yl carbamate. Appl. Biochem. Microbiol. 49, 502-506. doi: $10.1134 / \mathrm{s} 0003683813050086$

Liu, X., Yin, Y. N., Wu, J. B., Jiang, J. H., and Ma, Z. H. (2010). Identification and characterization of carbendazim-resistant isolates of Gibberella zeae. Plant Dis. 94, 1137-1142. doi: 10.1094/pdis-94-9-1137

Lucas, J. A., Hawkins, N. J., and Fraaije, B. A. (2015). The evolution of fungicide resistance. Adv. Appl. Microbiol. 90, 29-92. doi: 10.1016/bs.aambs.2014.09.001

Ma, Z., Yoshimura, M. A., Holtz, B. A., and Michailides, T. J. (2005). Characterization and PCR-based detection of benzimidazole-resistant isolates of Monilinia laxa in California. Pest Manag. Sci. 61, 449-457. doi: 10.1002/ps.982

Ma, Z. H., Yoshimura, M. A., and Michailides, T. J. (2003). Identification and characterization of benzimidazole resistance in Monilinia fructicola from stone fruit orchards in California. Appl. Environ. Microbiol. 69, 7145-7152. doi: 10.1128/aem.69.12.7145-7152.2003

Malandrakis, A. A., Markoglou, A. N., Nikou, D. C., Vontas, J. G., and Ziogas, B. N. (2006). Biological and molecular characterization of laboratory mutants of Cercospora beticola resistant to Qo inhibitors. Eur. J. Plant Pathol. 116, 155-166. doi: 10.1007/s10658-006-9052-1

Malandrakis, A. A., Markoglou, A. N., and Ziogas, B. N. (2012). PCR-RFLP detection of the E198A mutation conferring resistance to benzimidazoles in field isolates of Monilinia laxa from Greece. Crop Prot. 39, 11-17. doi: 10.1016/j.cropro.2012.04.001

Martin, L., and Martin, M. T. (2013). Characterization of fungicide resistant isolates of Phaeoacremonium aleophilum infecting grapevines in Spain. Crop Prot. 52, 141-150. doi: 10.1016/j.cropro.2013.05.023

Maymon, M., Zveibil, A., Pivonia, S., Minz, D., and Freeman, S. (2006). Identification and characterization of benomyl-resistant and -sensitive populations of Colletotrichum gloeosporioides from statice (Limonium spp.). Phytopathology 96, 542-548. doi: 10.1094/phyto-96-0542

McKay, G. J., Egan, D., Morris, E., and Brown, A. E. (1998). Identification of benzimidazole resistance in Cladobotryum dendroides using a PCR-based method. Mycol. Res. 102, 671-676. doi: 10.1017/S095375629700542X

Oakley, B. R., and Morris, N. R. (1981). A $\beta$-tubulin mutation in Aspergillus nidulans that blocks microtubule function without blocking assembly. Cell 24, 837-845. doi: 10.1016/0092-8674(81)90109-4

Olejnikova, P., Ondrusova, Z., Krystofova, S., and Hudecova, D. (2010). Benomyl-resistant mutant strain of Trichoderma sp. with increased mycoparasitic activity. Folia Microbiol. 55, 102-104. doi: 10.1007/s12223-0100016-7

Orbach, M. J., Porro, E. B., and Yanofsky, C. (1986). Cloning and characterization of the gene for $\beta$-tubulin from a benomyl-resistant mutant of Neurospora crassa and its use as a dominant selectable marker. Mol. Cell. Biol. 6, 2452-2461. doi: 10.1128/mcb.6.7.2452
Quello, K. L., Chapman, K. S., and Beckerman, J. L. (2010). In situ detection of benzimidazole resistance in field isolates of Venturia inaequalis in Indiana. Plant Dis. 94, 744-750. doi: 10.1094/pdis-94-6-0744

Scalliet, G., Bowler, J., Luksch, T., Kirchhofer-Allan, L., Steinhauer, D., Ward, K., et al. (2012). Mutagenesis and functional studies with succinate dehydrogenase inhibitors in the wheat pathogen Mycosphaerella graminicola. PLoS ONE 7:e35429. doi: 10.1371/journal.pone.0035429

Schroeder, W. T., and Provvidenti, R. (1969). Resistance to benomyl in powdery mildew of cucurbits. Plant Dis. Rep. 53, 271-275.

Sheir-Neiss, G., Lai, M. H., and Morris, N. R. (1978). Identification of a gene for $\beta$-tubulin in Aspergillus nidulans. Cell 15, 639-647. doi: 10.1016/00928674(78)90032-6

Shi, H. J., Wu, H. M., Zhang, C. Q., and Shen, X. (2013). Monitoring and characterization of resistance development of strawberry Phomopsis leaf blight to fungicides. Eur. J. Plant Pathol. 135, 655-660. doi: 10.1007/s10658-0120102-6

Sierotzki, H., Frey, R., Wullschleger, J., Palermo, S., Karlin, S., Godwin, J., et al. (2007). Cytochrome $b$ gene sequence and structure of Pyrenophora teres and P.tritici-repentis and implications for QoI resistance. Pest Manag. Sci. 63, 225-233. doi: 10.1002/ps.1330

Suga, H., Nakajima, T., Kageyama, K., and Hyakumachi, M. (2011). The genetic profile and molecular diagnosis of thiophanate-methyl resistant strains of Fusarium asiaticum in Japan. Fungal Biol. 115, 1244-1250. doi: 10.1016/j.funbio.2011.08.009

Thomas, J. H., Neff, N. F., and Botstein, D. (1985). Isolation and characterization of mutations in the $\beta$-tubulin gene of Saccharomyces cerevisiae. Genetics 111, 715-734.

Trkulja, N., Ivanoviæ, Ž., Pfaf-Dolovac, E., Dolovac, N., Mitroviæ, M., Toševski, I., et al. (2013). Characterisation of benzimidazole resistance of Cercospora beticola in Serbia using PCR-based detection of resistance-associated mutations of the $\beta$-tubulin gene. Eur. J. Plant Pathol. 135, 889-902. doi: 10.1007/s10658-012$0135-\mathrm{x}$

Vargas, J. M. (1973). Benzimidazole resistant strain of Erysiphe graminis. Phytopathology 63, 1366-1368. doi: 10.1094/Phyto-63-1366

Vela-Corcia, D., Bellon-Gomez, D., Lopez-Ruiz, F., Tores, J. A., and PerezGarcia, A. (2014). The Podosphaera fusca TUB2 gene, a molecular "Swiss Army knife" with multiple applications in powdery mildew research. Fungal Biol. 118, 228-241. doi: 10.1016/j.funbio.2013.12.001

Weatherbee, J. A., and Morris, N. R. (1984). Aspergillus contains multiple tubulin genes. J. Biol. Chem. 259, 15452-15459.

Wheeler, I. E., Kendall, S. J., Grosjean-Cournoyer, M. C., Butters, J. A., and Hollomon, D. W. (1995). "Molecular analysis of benzimidazole resistance in Rhynchosporium secalis," in Antifungal Agents: Discovery and Mode of Action, eds G. K. Dixon, L. G. Copping, and D. Holloman (Oxford: Bios Scientific Publishers Ltd), 257-261.

Wong, F. P., De la Cerda, K. A., Hernandez-Martinez, R., and Midland, S. L. (2008). Detection and characterization of benzimidazole resistance in California populations of Colletotrichum cereale. Plant Dis. 92, 239-246. doi: 10.1094/pdis92-2-0239

Yan, K., and Dickman, M. B. (1996). Isolation of a $\beta$-tubulin gene from Fusarium moniliforme that confers cold-sensitive benomyl resistance. Appl. Environ. Microbiol. 62, 3053-3056.

Yan, L. Y., Chen, J., Zhang, C. Q., and Ma, Z. H. (2008). Molecular characterization of benzimidazole-resistant isolates of Cladosporium fulvum. FEMS Microbiol. Lett. 278, 242-248. doi: 10.1111/j.1574-6968.2007.00999.x

Yin, Y. N., Liu, X., Shi, Z. Q., and Ma, Z. H. (2010). A multiplex allelespecific PCR method for the detection of carbendazim-resistant Sclerotinia sclerotiorum. Pestic. Biochem. Physiol. 97, 36-42. doi: 10.1016/j.pestbp.2009. 12.002

Young, J. R., Tomaso-Peterson, M., de la Cerda, K., and Wong, F. P. (2010). Two mutations in $\beta$-tubulin 2 gene associated with thiophanate-methyl resistance in Colletotrichum cereale isolates from creeping bentgrass in Mississippi and Alabama. Plant Dis. 94, 207-212. doi: 10.1094/pdis-94-20207

Zhang, C. Q., Liu, Y. H., and Zhu, G. N. (2010). Detection and characterization of benzimidazole resistance of Botrytis cinerea in greenhouse vegetables. Eur. J. Plant Pathol. 126, 509-515. doi: 10.1007/s10658-009-9557-5 
Ziogas, B. N., Nikou, D., Markoglou, A. N., Malandrakis, A. A., and Vontas, J. (2009). Identification of a novel point mutation in the $\beta$-tubulin gene of Botrytis cinerea and detection of benzimidazole resistance by a diagnostic PCR-RFLP assay. Eur. J. Plant Pathol. 125, 97-107. doi: 10.1007/s10658-0099462-y

Zou, G., Ying, S. H., Shen, Z. C., and Feng, M. G. (2006). Multi-sited mutations of $\beta$-tubulin are involved in benzimidazole resistance and thermotolerance of fungal biocontrol agent Beauveria bassiana. Environ. Microbiol. 8, 2096-2105. doi: 10.1111/j.1462-2920.2006. 01086.x
Conflict of Interest Statement: The authors declare that the research was conducted in the absence of any commercial or financial relationships that could be construed as a potential conflict of interest.

Copyright () 2016 Hawkins and Fraaije. This is an open-access article distributed under the terms of the Creative Commons Attribution License (CC BY). The use, distribution or reproduction in other forums is permitted, provided the original author(s) or licensor are credited and that the original publication in this journal is cited, in accordance with accepted academic practice. No use, distribution or reproduction is permitted which does not comply with these terms. 